\title{
Greek, Hellenistic and Roman-Byzantine Water Management Technology: Overview from Jordan
}

\author{
Mansour A Shqiarat* \\ Department of Archaeology, Al-Hussein Bin Talal University, Jordan
}

*Corresponding author: Mansour A Shqiarat, Department of Archaeology, AlHussein Bin Talal University, Jordan.

Received Date: February 14, 2019

Published Date: March 25, 2019

\begin{abstract}
Because of the widespread effects of Greece and Rome, and the characteristic and easily recognized styles of their monumental architecture and material culture, the issue of their water-management technology is treated here in a separate research. What is agreed upon to be either Hellenistic or Roman-Byzantine in Jordan and the theoretical and classificatory problems of interpretation are discussed in the subsequent research - has a critical effect on how the 'indigenous' or Nabataean water-management regime is identified and understood. It is fair to say that there is, at present, considerable confusion over the chronological and typological development of water management structures in Jordan between the middle of the first millennium $\mathrm{BC}$ and the middle of the first millennium $\mathrm{AD}$ which is the main thing this paper aims to begin to clarify. This paper, therefore, discusses what is known in general about the development of water management in what can be loosely termed the 'Classical World', based on both archaeological and historical sources.
\end{abstract}

Keywords: Jordan; Nabataean; Classical world; Waterworks; Technology

\section{Water Management Technology}

The Greeks were the first to use the basic water supply elements collectively to serve the needs of the entire urban community, including obvious display and aesthetic uses. They were also the first to divide water into the three categories of potable, sub-potable and non-potable on the basis of source and use [1]. The Greeks preferred to obtain potable water, that is., drinking and cooking water, from a flowing source such as a spring or fountain. This accounted for less than six percent of their total water supply [1]. Cisterns primarily supplied water for the sub-potable category. It is interesting that the Greeks also generally reused their water [1], what is today referred to as grey water. Non-potable wastewater, runoff, was used for irrigation, baths and sacrificial basins [1].

It has been suggested that several water components, such as gravity-fed conduits and pressure pipelines, were developed in the distant past and forgotten, only to be rediscovered at a later time [1]. It is also probable that some general concepts of water conveyance were shared by cultures as they came into contact with one another. One such possibility is the idea of subterranean water conduits. Several scholars believe that the idea was transferred from the Armenians to the Persians, then on to the Greeks and then to the Romans [1-4]. Each group, however, adapted the concept to fit its own situation and needs.

Household courtyards provided the primary location for domestic cisterns, supplying water for home-oriented and light industrial tasks, which took place in the open surroundings. From here the cistern accommodated the water needs of the nearby kitchen, as well as the laundry and washing needs of the household [1].

In the Near East, water was at once a bare necessity and the greatest of luxuries. Due to the limited availability of water throughout much of the region, research shows that the evolution of civilisation and irrigation technology is closely intertwined. As a labour-intensive requirement for agricultural productivity, complex irrigation systems were often dependent upon organisation and control by a central authority $[5,6,7,8,1]$.

As with all things water-related, however, such distinctions varied according to local circumstances. At Delos, for example, adequate ground water enabled the population to rely almost 
exclusively on wells and cisterns, clearly distinguishing the well water used for drinking from that of cisterns used for household and light industrial uses [1]. The springs at Priene provided the city with so much flowing water that the inhabitants used it for everything. With seventy five percent of all households having direct access to fresh water, few had the need to construct cisterns or wells [1].

Athens, although not necessarily regarded as a typical polis, contained a multitude of wells and cisterns, as the Agora excavations of the American School of Classical Studies demonstrate. These excavations uncovered more than 400 wells in the Agora alone [9]. Analysis of cistern and well construction for the sixth through fourth centuries BC reveals that, during the earlier two centuries, Athenians used wells exclusively, while use of cisterns and draws shafts dominated the later century. This change was due partly to the draw down theory and partly to drought, both of which caused the water table to drop. The actual location of the wells and cisterns within the Agora is not as important as their large numbers in a relatively small area, suggesting that they were the primary means of supply in Athens during the sixth through fourth centuries BC and that they provided public, not private, water supply [9]. However, in Antiquity its reality also struck hard, as in $413 \mathrm{BC}$, when the Athenians and their allies, having failed to take Sicily, were held for eight months in quarries on the island and were provided with only one-half pint of grain and water per day [10], approximately onethird of the daily requirement. This situation, along with exposure, crowded conditions and disease, caused great loss of life.

While classical Greek residences continued to have their own water provision, usually supplied by a well or cistern, there were also fountains and springs protected, maintained and enhanced by the local authorities for public use [11]. Greek fountains were built or excavated around a natural spring; a series of reservoirs behind and draw basins in front collected the water. The fact that the area around fountain houses was left open indicates that it was built to serve larger numbers of individuals [12].

The leaders of the Greek poleis took an interest in supplying clean water for everyone in their cities. Thegenes of Megara, Gela of Syracuse, and Solon, Peisistratus, Cimon and Pericles of Athens are only a few who, either through laws or actual construction, used their leadership positions to Marshall Men and resources to improve the urban water supply [1].

Recalling the action of Solon in the 590s BC, Plutarch wrote that, because the country was not well supplied by rivers, lakes or springs, people were to use the public wells within a hippikon of their residence, about $0,8 \mathrm{~km}$; if they lived further from a public well than that, they were to use their own wells. If, however, they dug a considerably deep well and still did not reach water, they could fill a jar twice a day from their neighbour's well. Solon did this, according to Plutarch, because he felt it was his duty to assist the needy, but not to aid the idle (Plutarch 1997: 23-5) [9].

Plutarch's account reveals much about the water needs of the people of Athens and Solon's actions, and it supports the finding of the American School's Agora excavations. It is unfortunate that Plutarch does not inform his reader whether Solon had additional public wells dug or relied on those already there.

Thucydides noted how Peisistratus assisted in public waterworks by converting the Kallirrhoe spring into a nine spouted fountain house, the Enneakrounos, although he stated that it was used primarily for ceremonial purposes $[9,10,13]$ while Plutarch related how Cimon changed the Academy from a bare and dusty spot to a "well-watered grove" [14-16].

Other Athenian leaders also served the public's interest in posts concerned with water administration. For example, Themistocles served as an apostate of waterworks early in his career. He dedicated the Water Carrier, a bronze statue of a maiden, paid for by the fines he collected while in that position from people who had stolen or illegally tapped the public water supply $[9,17]$. These illegal actions, however, did not end with Themistocles' fines. The epistates of water, a superintendent of fountains, was an elected position in Athens, like the strategic or generals, rather than one chosen by lot. This alone shows how important the people considered this position to be. Although most wealthy cites appear to have had more elaborate and expansive water supply systems, they could also be found to have systems which were outdated or inadequate, as in the case of [1].

While many of the examples given here depict an expanded system for Athens, the city was actually behind in the incorporation of available technology by the Hellenistic era. The problems with the draw down theory and the depletion of subsurface aquifers contributed to the problems which the city faced. When populations expanded or when conveying water was more feasible than transporting fertile soil, the Greeks created long distance waterlines [1]. These aqueducts were primarily subterranean and followed land contours [1]. Theagenes, the tyrant of Megara, had an underground tunnel system and end fountain house constructed to provide his city with water (Withe 1984: 158). This seventh century project appears to be the earliest Greek underground tunnel system with end fountain. It is unfortunate that not much is known about its construction or use [18].

A better-documented and explored tunnel system can be found on Samos. Regarded by Herodotus as one of the three greatest works of the Greeks [19], it is traditionally credited to an imported Megarian architect. Unlike Megara, however, the Samian system is not one channel but two. Workers dug the main tunnel so that they would have space to work, while the second, the actual water carrier, was cut against the side of the first tunnel wall and into its floor. This channel within a channel method of conduit construction can be found elsewhere and in later periods.

Probably the most elaborate and impressive Greek aqueduct systems are found on the island of Sicily. Engineers working for the tyrants of both Agrigentum (Akragas) and Syracuse constructed extensive water systems. The engineer Phaias is associated with the early fifth century BC efforts at Agrigentum, but Diodorus reported that Carthaginian prisoners built pipelines (drainage), some of 
which brought water to an ornamental lake, a kolymbethra, which was also used as a fish hatchery and scenic spot [20-22, Finley 1968: 53). It is probable that, as early as the sixth century, workers, whether prisoners or freemen, enlarged the natural karst channels which underlay the area, reinforcing the tunnels where necessary and sinking vertical shafts $90 \mathrm{~cm}$ in diameter along its route.

At Syracuse natural water tunnels virtually honeycombed the plateau on which the city sat. As new parts of the city become occupied, often by an influx of settlers from other cities, the tyrant Gela enlarged and utilised many of the natural tunnels as aqueducts to supply the population with fresh water [1]. As with the waterworks at Agrigentum, vertical shafts provided access to the water channels. At least six different Syracusean tunnel systems have been found and identified; one, the aqueduct of Galermi, is possibly that cut by the Athenian besiegers in $414 \mathrm{BC}[10,21]$. Because they are part of the karst terrain, these Sicilian aqueducts are themselves water collectors, not simply water conveyors, gathering water which seeps through the aquifer us formation; the collected water is then carried in a depression cut into the channel floor [21].

Classical Greeks also used underground terracotta pipelines and stone channels. Some ceramic pipeline sections had lidded holes which served as access points. Others were constructed of limestone blocks into which a channel was cut $[9,23]$. The resulting elevated ledges on each side of the latter helped workmen access and maintain the system without getting into, or shutting off, the water. Such shelves could even accommodate pipes added to supplement the channel flow $[9,23,24]$.

The end of the classical and the beginning of the Hellenistic period of trend to utilise water supplies from a further tailed and with high elevations than those previously tapped. The cause of this increase in long distance lines was either increased demand or a drop in the immediate water table [1]. The two are not mutually exclusive, in that large usage results in a drop in water table. An example of this can be seen at Morgantina, where the sixth century $\mathrm{BC}$ aqueduct served the city population's needs adequately until the Hellenistic period; after that it was necessary to supplements the city's water supply by additional water lines, cisterns, and wells [1]. It is also at the beginning of the Hellenistic period that settlement began to establish large public water reservoirs either inside or immediately outside the urban demarcation [1].

Hellenistic water systems tended to mirror the political changes which were taking place, especially the desire for gigantism [1]. Along with the desire to create large monuments, the Hellenistic period's civic water supply systems reflect the increased wealth, territory and luxury desired and accomplished by the new dynastic rulers. For the first time on a large scale Hellenistic rulers had both the power and the financial resources to undertake elaborate building programmes' not only in their own cities but elsewhere throughout the Greek world $[18,25]$.

Technologically, the Hellenistic era surpassed its predecessors by the development and utilisation of such impressive water components as inverted siphons [18]. A primary difference in Hellenistic and Roman siphons is that the former were usually single pipes of terracotta or stone while the latter were often multiple pipes of lead [18]. By far the most impressive example of this technology can be found at Pergamon, where, until the reign of Attalos I and his successor Eumenes II, people relied primarily on wells and cisterns to satisfy their needs. Both rulers fostered the provision of public water supply to the city, bringing water under pressure through pipes from the surrounding territory to fill reservoirs within the city [26].

In Jordan a site dating to the Hellenistic period, Iraq Al-Amir (Al-Abd Palace) built by Hercanus during the reign of Seleucus IV (2nd century BC) and now lying $20 \mathrm{~km}$ west of Amman in the Wadi Al-Sair area is the most important. The palace contains a water system consisting of a water basin fed by more than 20 adjacent springs two reservoirs; were used for accumulating water channels, irrigation canals, a large pool used for reserving water for farming purposes; and a great dam whose purpose was to prevent soil erosion and water contain in the pool, were located to the north palace $[2,27]$.

In the 8th century BC, the ancient kingdom of Saba in modern Yemen greatly enhanced agricultural production by constructing a dam 16 metres high and 680 metres in long at Ma'rib [28]. For more than a millennium the lake that formed behind the Ma'rib dam provided enough water to irrigate fields that sustained a population of around 50,000 people. A long, detailed inscription dated to Sasanian $455 \mathrm{AD}$ reveals in a catalogue of events that 20,000 people were involved in repairs to the dam [29].

The aqueduct of Eumenes II was a triple terracotta pipeline at the end of which was a $3.2 \mathrm{~km}$ long siphon with a steepness unknown elsewhere in Antiquity [18], the goal, however, was to bring water to public reservoirs rather than to individual structures. Fahlbusch considered that these urban tanks, not the aqueduct with its siphon, were the mainstay of the civic water system, and estimated that the water stored within them could sustain 20,000 people for one year if the city were besieged [26]. This continued concern with creating an internal water supply and protecting it from enemy forces is echoed in Pergamene legislation, which made sure that private residences continued to maintain and keep clean their own cisterns in the event of a siege [30]. In the 7th century BC, the Assyrian king Sennacherib built an aqueduct to transport water from the eastern mountains to his capital at Nineveh, a distance of 55 kilometres [31].

Courtyard cisterns continued to provide individual homes with most of the sub-potable water they needed [32]. Cisterns from this period were usually bottle or flask-shaped, a design developed over time to keep the water at greater deeps, allowing for less evaporation and cooler temperature. Most cisterns were also plaster-lined to help waterproof the cavity [33,34].

Elsewhere, particularly in Palestine, Hellenistic cisterns were often stepped [35]. The standard head for both wells and cisterns from this period appears to be stone or terracotta cylinders 
(Puteals) [1]. It is possible that masonry heads were used in areas of heavier, more demanding work such as in shops or at the back of houses [36].

Public, rather than private, water supply continued to be the primary concern of the authorities who increased urban water supply. At Morgantina and Agrigentum, cut or pipe waterlines are always found associated with baths, fountains and tanks and sometimes springs [1]. Priene's aqueduct brought water to a civic reservoir from which pipes conveyed the water to small stone corner fountains throughout the city and possibly to the gymnasium $[30,37]$. The same scenario can be found at Antioch on the Orontes, where the karst terrain of the Daphne plateau produced sufficient springs to allow the channelling of water to fill urban reservoirs [38,39].

The Hellenistic era saw the continued use of subsurface tunnels to convey water from a distance, usually taking advantage of the underlying geology. A good, but not well known, Hellenistic water supply which included such tunnels can be found at Acre-Ptolemais in Palestine [40]. Tentatively dated to the fourth or third century $\mathrm{BC}$, this aqueduct conveyed water from the Kabri springs to the city, a distance of approximately $13 \mathrm{~km}$. Workers constructed the tunnel by digging toward one another from vertical access shafts (putei), about $53-54 \mathrm{~m}$ apart. The intersection of the shafts and the horizontal tunnel differed depending on geology, distance to the surface, and probably crew preferences. Intersections were vertical, angled or stepped. Lamp niches cut into the tunnel walls assisted workmen in illuminating the interior so that they could work. These niches were found on opposite sides of the horizontal tunnel walls, apparently cut so that light would come over the left shoulder of the workers. Many of the traits found in Hellenistic water supply systems are also found in Roman ones [40].

Recent investigation of settlement patterns in the late Hellenistic and early Roman periods, at least in Greece, has shown a marked drop in rural population and a rise in population in "nucleated settlement", that is cities [41]. The realignment in city population can be understood for the periods in question because of warfare and brigandage, and appears to have stabilised in the Principate under the Pax Romana and remained stable until approximately the fourth century [41].

The aqueducts of the early republic mirrored Greek and most Hellenistic systems, being primarily underground tunnels, necessitated by the continued need for security and defence [42], and by the lack of concrete technology. In the Hellenistic period, aqueducts were utilised in the desert regions of Syro-Palestine to manage flash flooding and to transport water for irrigation and storage purposes [43].

As was seen beginning in the Hellenistic period, more and more water was needed to meet luxury consumption. Such demands usually required tremendous amounts of water to be brought into an urban setting. Luxury items in this case included those things associated with prosperity, not mere existence, and the niceties of urban life, such as water for decorative fountains and pools, baths, nymphaea and gardens. As was the case at Morgantina, Agrigentum, Pergamon and many other Hellenistic cities, long distance waterlines were usually associated with baths and fountains [1]

For the builders of Greek or Hellenistic water supplies, an aqueduct generally meant a pipeline rather than an open channel, although they, too, constructed both types (Aicher 1995:11). The difference lay not only in the fact that one is under pressure and the other is not but also in the amount of water that each could provide. When the Roman did use pipes, they were usually for the subsidiary sections of the system, that is, within a city rather than without, and they could be of lead, a material which does not appear to have been used for such purposes in the Greek or Hellenistic eras. Finally, before the Principate, pipelines usually brought water to a fountain house or to public reservoirs [1].

The emphasis was on public or general provision of water. With the advance of the Principate, lines could not only go to public installations, such as baths and fountains, but also to private residences. Greek and Hellenistic long distance waterlines might have been modest and durable, but Roman ones were durable and spectacular [1].

During the 2nd and 3rd centuries, as a result of stability, agricultural settlements had dispersed and expanded all around the region; many wells and water reservoirs were established. Some of the examples are in Amman (Philadelphia), where a large circular pool $5 \mathrm{~m}$ high has been discovered. The pool had stairs leading to the bottom and its interior sides were plastered with a layer that prevents water seepage to the outside; several canals connected with this pool and fed it with water [2,44]. Jerash is anther example characterised by a fertile location and abundant water sources a water system has been revealed; there that contains pools for reserving water evaporation. The Romanian city of Jerash also has watering canals, some of which are carved in rocks and others built from plastered stones [2].

Tubes made from both pottery and leads have also been discovered. These were used for channelling water to houses, baths and charitable public fountains, in addition to a system of waste water outlets outside the city's utilities [45].

On the other hand, in the Byzantine city of Jerash, built on Roman foundations, the water facilities built by the Romans remained in use. This included public baths a large pool, and a charitable public fountain. All these were supplied ultimately from a spring about one kilometre north of Jerash, in the same valley. At this point two artificial pools were constructed (the constricted topography not allowing a single large pool to be practically possible) $[45,46]$.

At the site of Abu-Thuwab on the Amman Jerash highway, many houses made of stone have been discovered. The main watersupply source is variable rather than invariable, so people found themselves forced to move on to other places during dry seasons $[2,47]$

During the Roman period, Roman citizens from the Italian peninsula were rarely found outside the government or army in 
the Near East. Greeks were present but were few in number and found mainly in urban canters. The majority of the population by far was Semitic. Many urban native (Semitic) peoples throughout the eastern provinces, however, were Hellenised in language and culture to some degree. Numerous Greek inscriptions indicate that the urban upper class was made up of Hellenised Semites. The rural population is presumed to have remained Semitic in language and culture. Latin is rarely seen in inscriptions and Greek is much more common. Soldiers from distant provinces settled and intermarried in the eastern provinces and, though most of the approximately 100,000 Roman soldiers were foreigners from throughout the empire, soldiers were recruited in the east as well $[2,48]$.

During the Byzantine period, the western part of the Empire, consisting of the Italian peninsula and North Africa, used Latin as the language of education and administration, whereas in the eastern section, meaning Greece, Anatolia, the Levant and Egypt, it was Greek. However, most people within the Byzantine Empire spoke neither.

In northern Jordan, as in most of the Levant, Aramaic would have been the common spoken language, with Greek spoken by educated officials primarily in urban areas, such as the Decapolis cities, which were established during the Hellenistic period. A multitude of languages and dialects were spoken within the empire, as would be expected within such a large geographical area containing a variety of ethnic groups. As a result, people probably did not identify themselves as belonging to the Roman Empire. Instead, people emphasized their local origin and religion for purposes of self-identification.

Indeed, Christianity was the one aspect of Byzantine life that served to unite people and gave them a feeling of cohesion (Mango 1980). Based on numerous inscriptions from the area, the majority of the population was of Arab origin but not necessarily nomadic or even semi nomadic. The conversion of Arab tribes to Christianity was a factor in encouraging them to become sedentary. During the 4th century AD, 'abishop of tents' was responsible for nomadic Christians [49]. There is no indication of major population replacement after the Muslim conquest, although some people did leave the eastern provinces, including some Greeks, surviving Byzantine troops, monks and the Ghassanid tribal chief Jabal and his followers [50].

Most data on pagans during the 5th century. Comes from Christian sources and usually deals with urban areas. Little is written concerning the surrounding countryside. Pagans during the Byzantine period in the east were known as Hellenes, meaning Greeks. Both the pagans themselves and Christians [51] used this term. In $423 \mathrm{AD}$, the edict of Honorius and Theodosius claimed that there were no more pagans in the Holy Land [52].

\section{Northern Jordan from the Roman through Early Islamic Periods}

The Seleucid Empire came to an end in the late 2 nd and early $1^{\text {st }}$ centuries BC. The power vacuum left by the collapse of the Seleucid
Empire allowed the Nabataean and Jewish Hasmonean kingdoms to grow. The result was instability and conflict, which came to an end with the arrival of the Roman general, Pompey in 63BC. The northern Hellenised communities of northern Jordan were released from Jewish and Nabataean control and attached to the Roman province of Syria for governmental purposes, although they maintained local autonomy $[2,48]$.

The Emperor Theodosius II stated, "The regulations of constitutions formerly promulgated shall suppress any pagans who survive, although we now believe that there are none" [51]. This is most probably a false claim, as proof of the persistence of pagan beliefs in the eastern provinces comes from the frequent issuing of official orders condemning it. Paganism was officially prohibited at some point during each of the following years: 399, 16, 23, 35, 51 and $472 \mathrm{AD}$ ([51]. Before the mid-5th century. Theodoret, Bishop of Cyrhus in Syria made statements indicating that there were no longer any pagans in the Empire.

"The earth and the sea are freed from ancient ignorance; the error of idolatry is no more, the shadows of ignorance are dispersed, and the light of knowledge fills the entire inhabited world with its rays. Greeks, Romans, and barbarians acknowledge the divinity of the crucified one, venerate the sign of the Cross, and serve the Trinity in place of the multitude of false gods...." [51].

However, there were evidently many pagans in Syria. Heliopolis/Baalbek was an important centre of pagan worship, and Christians were reportedly a minority there as late as the reign of Tiberius II (572-582) ([51]. Regarding the area of northern Jordan and southern Syria, the Bishop of Bosra claimed in 362 AD that Christians made up almost half of the population [53].

Though there were many anti-pagan laws, enforcement generally consisted of dealing only with those issues that were brought to the attention of the authorities. The continuation of pagan practices was due in part to the inability to enforce locally laws that were issued from the seat of the imperial government. Additionally, the Christological controversy (after the middle of the 5th C.) created a great deal of disagreement among eastern Christians. This controversy involved disagreement within the church as to the human and divine natures of Christ. Attention was diverted from pagans to some extent; anti-pagan laws did, however, make life difficult. Pagans were not allowed to make sacrifices, were excluded from civil service and were also not allowed to make wills. There were also severe penalties for allowing pagan worship on one's property. Naturally, such legislation led to many conversions to Christianity. The extent to which converts seriously believed in their newfound faith is questionable under such circumstances [51].

At the turn of the 4th and 5th centuries, no more than half the population of the Levant and the whole region from the River Euphrates to Egypt had been converted to Christianity [54]. It is doubtful that by the 5 th c. The population of any given province consisted of a majority of pagans. They had most likely diminished to no more than $1-2 \%$ by $500 \mathrm{AD}$ [51]. 
Prior to the coming of Islam, Christianity was the dominant religion in the region [55]. Much of the population likely remained Christian after the initial Islamic conquest, but some churches and synagogues were turned into mosques. New mosques were also constructed $[48,56]$.

Carefully repaired damage of mosaic floors may have been carried out deliberately by Christians [50]. If true, the motivation of these Christians is under, as the damage and repair seem to have little to do with iconoclasm in the Byzantine Empire, where ordinary images were not a problem. The Muslim Caliph, Yazid II, issued an iconoclastic edict in $721 \mathrm{AD}$. The relationship between this edict and damage done to mosaic figures is uncertain, especially given the careful manner in which many were repaired. Caliph Yazid II died in what is modern-day Irbid in 724, indicating the presence of Muslims in northern Jordan by at least the early 8th century. The presence of carefully repaired damage to church mosaics at the sites of Yasileh, Dohaleh and Ya'amun attest, to their continued use by Christians. Christian communities were thriving at the beginning of the 7th century and were, in many places, still practicing their faith through the early 8th century. By the early Abbasid (750-878 AD), however, the number of Christians had declined significantly. This is not the same as an over population decline. Only around one-half of the churches in use in 602 were still being used in 813 . This is the result of the cumulative effect of ovens during the early Islamic period were rebuilt and others were abandoned. There were certainly cases of conversion for the Christian Church of the Byzantine Empire and the subsequent loss of state funds which put considerable pressure on Christians to convert [2,50,57].

In addition to the loss of official sources of revenue from the church and state, the Muslim conquest probably resulted in fewer pilgrims arriving from distant lands. Although difficult to quantify, churches in the Christian Holy Land would have received money for upkeep and construction as a result of the loss of private donations.

Christianity suffered a setback during the reign of Julian's polio (361-363 AD), a cousin of Constantine. Anti-pagan legislation was reversed and Christians were challenged by a variety of acts that reversed their earlier preferential status. Pagan temples were established in Transjordan, including at Bosra, where a dedicatory inscription dating 362 proclaimed the "restoration of Hellenism". A Christian ex-governor of Bosra had his property confiscated under the claim that it had previously belonged to a pagan temple. The governor of Arabia in 362-3 AD was a pagan. However, Julian's polio had no lasting effect on Transjordan. At least part of the population would have probably continued to be pagan without his encouragement and the setbacks of the Christian's were made up for under the short rule of Jovian (363-4) who reversed the antiChristian acts $[2,58]$.

Despite invasions by Sasanians and Muslims, rebellions by Jews and Christians, and raiding by nomadic Arab tribes, high population and settlement density and economic prosperity are distinct features of the Byzantine period in the Near East. This holds true for Palestine west of the Jordan River where, as early as 1958, archaeological surveys attested to the high level of development $[48,59]$.

Ancient written sources and archaeology both point to the 5th through to the early 7 th centuries as the period of highest population and settlement density in Palestine until the 20th century [60]. It is clear to archaeologists that Transjordan, the area east of the Jordan River, was also heavily settled in the Byzantine period with the peak beginning in the second half of the 5th century and reaching an apex in the 6th and 7th centuries [49]. Surveys in Jordan have identified Byzantine sites in all environmental and topographic regions, giving the impression of thriving towns and their interdependent countryside [48,61].

The effect of Roman administration on provincial economies has been debated, but there is no doubt that the needs of thousands of Roman troops and the imposition of taxes had some impact $[48,62]$. A direct comparison of taxation rates between the Roman and Byzantine periods is difficult but, with regard to Egypt, Justinian (98-117 AD) supposedly collected one-third more taxes than were collected by Augustus (27 BC), assuming that the amount of agriculturally productive land remained the same. Wages and the cost of living in Egypt changed little from the time of Augustus to the 6th century (West and Johnson). Trade was also subject to taxation, and in the first century of Roman rule in the Near East a duty of $25 \%$ was exacted on all imports, and also probably on exports along the eastern frontier. Starting in the 4 th and possibly the 3rd century $\mathrm{AD}$, this rate was halved to $12.5 \%$. In addition there were often local tolls that had to be paid (Richards 1974; 2,)[61].

The Empire collected taxes in three ways: cash, agricultural products from the producer and agricultural products paid by one who did not grow the crop. Tax in kind might have been collected in only certain products, forcing some farmers to transfer their own produce into cash for acquiring what could be used to pay taxes. Tax in kind requires a transportation system that allows the movement of bulk produce from the countryside to regional markets. Soldiers and officials received some part of their pay in kind. Taxes paid in kind were often given over directly to the Roman army [63-65]. believes that during the first two centuries AD, Roman Britain maintained its pre-Roman economy, where instead of using cash, exchange was dependent on personal and tribal relations.

In 4th century AD Palestine there is some evidence of decline in the agricultural economy, possibly due to the increasing tax burden imposed by Rome. Rabbinic sources from the 4th century $\mathrm{AD}$ even mention famine, allowing the possibility that the quality of the life within the Jewish community fluctuated during the early Byzantine period. Yet, despite high inflation, there seems to have been considerable wealth, much of it the result of money pouring in from abroad that was used to build churches and shrines [66].

This investment from outside sources was a result of the establishment of the region as the Holy Land after Christianity was made the state religion $[48,61]$.

One of the reasons for prosperity in western Palestine and Transjordan during the Byzantine period was probably the 
relative peace when compared to the western half of the Roman Empire. Though the Roman Near East witnessed frequent armed conflict, it was still more stable than the western half of the Roman Empire, which suffered successive waves of invasions from various European barbarians. [59] sees three main periods of monetary inflow: public investment under Constantine and his immediate successors (starting in approximately $330 \mathrm{AD}$ ); private investment in various forms until the death of Eudocia in $460 \mathrm{AD}$; and the reestablishment of public investment under Justinian (527-526 AD).

The private investment previously mentioned quite probably exceeded imperial moneys. Much of this donated money was from well-to-do refugees of Vandal and Gothic invasions in the west. Pilgrims from other lands also put money into the local economy while touring holy sites. Later pilgrims, however, were often without funds and probably represented a cost rather than an input of capital.

The economy of villages was based mainly on agriculture and secondarily on domestic animals such as sheep and goats. The agricultural, hunting and pastoral scenes that can be seen in mosaics were likely depictions of real life. The steppe region of northern Jordan between the Jordan River and the eastern desert was the site of vineyards and wheat and barley cultivation [49] (Shqiarat 2017). Abundant olive presses also attest to the establishment of farming in so-called marginal environments [48,61]. Olives of the Decapolis were considered to be of excellent quality and olives for food were exported to Rome (Safrai 1994).

Byzantine period rural settlements in northern Jordan were categorized by [49] as: walled fortified villages or villages near military stations mostly in the steppe; agricultural villages; and agricultural monastery communities. Some of the more studied sites of northern Jordan are the Decapolis cites, six of which are located in northern Jordan. In addition to the agriculturally productive countryside, the Decapolis and surrounding communities benefited from their location on caravan routes running from north to south and east to west. As the population was converted to Christianity, earlier pagan temples and Jewish synagogues were sometimes reconfigured as churches. Mosaic pavements with dedicatory inscriptions indicate the wealth of members of Byzantine communities and give the names of church and municipal officials $[2,48,61]$.

Mosaicists were either local or hired from outside by rich families to decorate churches. [49] sees two separate economic periods in Jordan based on a change in church building activity. At the beginning of the 5 th century and early 6th century AD, church building was pragmatic. In the second half of the 6th century the construction of new churches and refurbishment of older churches with mosaics and wall paintings became more ostentatious. This coincided with the re-establishment of state investment under Justinian (527-565 AD), as noted by [59].

The term Decapolis appeared in the 1st century AD. The Decapolis region was originally organized as an administrative unit of the province of Syria. The recruitment of Decapolis citizens into the Roman Army in Syria attests to the full integration of the Decapolis into the Roman Empire. With the annexation of the Nabataean Kingdom by the Roman Emperor Trajan in 106 AD, the cities of the Decapolis fell within the bounds of the three separate provinces of Arabia, Palaestina Prima and Palaestina Secunda [67]. This annexation was accomplished without a struggle on the part of the Nabataeans. Bostra (Bosra) became the capital of the new province of Arabia and a major highway was constructed that stretched from Bosra to Aila on the Red Sea $[48,61,58]$.

The Decapolis cities that lie within modern-day Jordan are Gadara (Umm Qais), Abila (Queilbeh), Capitolias (Beit Ras), Gerasa (Jerash), Pella (Tabaqat Fahl), Philadelphia (Amman) and, possibly, Dium (exact location currently uncertain). The Decapolis cities each administratively oversaw the surrounding countryside, forming a largely contiguous area. The Decapolis cities made up a distinct Greek cultural unit that differed from the surrounding, culturally Semitic regions. Each city saw a great deal of public building, mostly financed by local benefactors, implying local economic prosperity based on agriculture from the surrounding countryside. Decapolis cities also benefited from their geographic position that ensured a great deal of commercial traffic passing through their territory between Syria, Palestine and the coast, and Arabia. Economic prosperity continued under Roman rule through the 2nd and into the 3rd centuries AD. Many cities built major public works funded mostly by local elites but also by imperial patronage. Most of these cities began to mint their own bronze coinage (Shqiarat 2017; 2018) [48].

Each city had its own territory, and recent discoveries of a remarkable series of small stone boundary markers from second century $\mathrm{AD}$ at Jerash have highlighted the importance of such territories $[68,69]$. The location of the city's territory is important in many respects [68]. For the boundaries that have been demarcated, those of the east and south follow the watershed line between adjacent river basins. Crucially, the eastern boundary also coincides with the edge of the 300 millimetre precipitation isohyets and the southern part of the territory has been extended to include a portion of the important valley of the perennial River Zerka [68] The steppe lands begin to the east of the isohyet, which until recently marked the boundary between the sedentary farming of olives, fruits and wheat, and the pastoralism of Bedouin tribes $[2,68,70]$.

In the winter of 541-2, the bubonic plague affected all of the eastern provinces from Egypt through Asia Minor including the Levant. As much as one-third of the population may have died, and possibly more in heavily populated Constantinople. The plague is said to have recurred approximately every 15 years. It is uncertain whether the rural population was dense enough to sustain bubonic plague outbreaks. However, the loss of life was enough to result in the abandonment of some towns. The only real census figures for this time period are from the army. There was, apparently, no significant decline in the size of armies during this time, but they may have been drawn primarily from rural areas and not cities that were more likely to be affected by plague $[60,61,71]$. 
Many villages in Jordan that had been occupied since at least Nabataean and Roman times continued to be inhabited after the coming of the Umayyads, with little evidence of interruption $[2,48]$. Pella surrendered peacefully to Islamic forces in 635. Abila experienced no break in occupation until an earthquake in 747-8 that also affected Gadara. Jerash suffered an earthquake in 648, but witnessed a resurgence of activity under Umayyad rule. The encroachment of construction into streets in urban areas indicates a still growing population. The number of churches and synagogues provide evidence that the population remained primarily nonMuslim during the early Islamic period. Northern Palestine and Jordan benefited greatly from their proximity to Damascus, the capital of the Islamic Caliphate $[55,72]$.

One of the most common means of water supply in Antiquity was the excavation of wells, although it seems that in north-western and central Europe true wells were dug only as the result of direct Roman activity, or at least under Roman influence [73]. Cisterns were usually much easier to construct than wells and enabled individuals more freedom from the dictates of geology and ground water. Cisterns, usually filled by roof run off, are by far the most common means of water supply for private residences [1].

As Roman control secured additional territory, engineers began to leave more of the water conduits above ground when practical. This allowed builders to take greater advantage of the terrain through which a conduit had to pass and made the channels easier to construct and to maintain. Elevated sections, although representative of only a small portion of an aqueduct, have always attracted the attention of visitors and specialists more than any other component. As Frontinus stated, "with such an array of indispensable structures carrying so much water, compare, if you will, the idle pyramids or the useless, through famous, works of the Greeks" [74].

Wells and cisterns, however, also continued to be used, usually meeting different needs of households [36]. A small but revealing example can be found in the houses at Herculaneum [36]. Of the six houses which had cisterns, four also had piped water; three of the eleven houses with wells also had piped water; one house had both a cistern and a well but no piped water. To look at it in a slightly different way, seven of the twelve houses (58\%) known to have had piped water also had either a well or a cistern. In the Roman period, this budding luxury use of water blossomed into obvious display; it might even be said that what was once considered luxury and opulence became regarded as common requirement in some instances. Pliny stated that Roman aqueducts made it all possible; he further elaborated that if one added to that their distance, construction and routes, then all would agree that they were the most remarkable items in the whole world $[2,75]$.

Roman elevated aqueducts had certain common features, although each aqueduct did not necessarily need all the components or have them in the same sequence [76]. Materials used in construction varied depending on what was locally available. The engineers who built these channels took advantage of the terrain through which the aqueducts were built, taking special care to obtain the desired gradient for the water channel (specus). This meant that arcades, bridges, or substructures (embankments) were used as necessary. Settling tanks or, more appropriately, settling areas' can sometimes be identified along the course of an aqueduct (Aicher 1995: 10,43). Although most Roman aqueducts are remembered because of their stunning bridges or impressive arcades, most of them also had subterranean sections. To build the tunnel sections, workers dug vertical or angled shafts (putei) to the desired level and then connected them by means of a horizontal channel. When the water channel was exposed, that is., when it was above ground, it was lined with hydraulic plaster and covered with stone slabs. Once the water arrived in the city it was usually deposited in a primary castellum (water distribution point), located at a high point from which water was further distributed by means of pipes and/ or possibly castella. The destination was usually a high water-use installation or area, for example, a bath, a fountain near apartments which had no other water supply, or private houses $[2,36]$.

How the Emperor Justinian solved such a problem for his capital when it was suffering from summer droughts and reduced output from the spring-fed aqueduct. Justinian's engineers excavated a large storage reservoir beneath the Imperial Portico in Constantinople, derogated to hold the normal aqueduct overflow usually wasted in spillage (Procopius of Caesarea De Aedificiis: 1-11).

It should be remembered that, even in the Roman period, aqueducts were not the only components of a water supply system. Even when and where such impressive channels were built, societies also utilised other elements of the system, such as wells, cisterns, rivers and springs to meet their water needs. Particularly in the East, where climate, rainfall, subsurface water tables and geology could be quite different from what was encountered in the west, aqueducts were characteristically only one component of a vast water supply system, and viewed as subsidiary in some respects [77].

In the late fourth century $\mathrm{BC}$, the city of Rome received its first aqueduct, the Appia, sponsored by and named after the censor Appius Claudius Caecus. Like most other conduits of the time, it was built underground because of the concern for security $[74,78,79]$. Within fifty years, Rome had a second aqueduct, the Anio (Vetus). It, too, was built primarily below ground, but emerged above ground on arches just outside the city [74]. The city was still too insecure for more of the structure to be exposed [79]. With Rome's ever-expanding sphere of interest and its accompanying increase in income there came increased desire for luxury and all the items and structures associated with it, including those related to water. Additional water demands, therefore, came to the forefront [42]. With the sound basis of water supply developed in other cultures, supplemented by Rome's ideas of expanded supply, usage and grandeur, Roman aqueducts became true national structures [80].

The lure of so much easily accessible water, water which did not have to be carried, proved tempting to some individuals who tapped the public channels to bring the elements to their private 
homes and gardens. As censor, Marcus Cato cut some of these illegal pipelines, but the problem seems never to have been solved completely (Levey 1975: 29-44).

Even so, a large portion of the Roman population continued to obtain water from wells and cisterns; security, engineering technology and building techniques had not yet progressed to the point where these structures can be viewed as completely Roman. They were instead basically Hellenistic waterworks, but the use of the arcade in the building of the Anio told of impending changes. While the construction of two aqueducts in a relatively short time reveals that the Romans already had a desire and need for greater quantities of easily obtainable water, Cato's efforts to stop the illegal tapping of the aqueducts exhibits the increasing Roman desire to have large amounts of water for private households and gardens, in addition to increased public demand.

The reign of Augustus created a boom in elevated aqueducts. One reason for this was the end of the civil war in Italy and the long-awaited Pax Romana. With peace, and the fact that Rome now virtually controlled the entire Mediterranean, waterworks no longer had to be hidden below ground. The peace also meant that civic boundaries could now be crossed by herdsmen, roads and aqueducts [41].

Security also allowed growth of trade and industry, bringing about a general increase in urban wealth throughout the Empire that could be devoted to luxury. Vitruvius wrote that water was necessary for life, daily use and delights (delectiones) [81]. Frontinus echoed this sentiment when he wrote that the great volume of water furnished by the aqueducts was for public and private uses as well as a response to the desire for luxury [74,75].

Christer Burns, in his study of the Roman water system, states that the constant uninterrupted flow of water was considered a sign of wealth and a high standard of living [21]. Many of the specific symbols of delight and luxury, including baths, fountains, pools, naumachiae, nymphaea and related pleasure- sonrces, involved water best provided by elevated aqueducts [82,83]. These are the elements one author has dubbed "the seductive trappings of civilisation...." [84].

In Rome itself, Augustus's friend, M.Vipsanius Agrippa, became the force behind the new methods of water provision and the expansion of pleasure and luxury related attractions $[79,85,86]$. The Aqua Julia built, to satisfy the expanding demands of the growing city $[2,74,79]$, was the first aqueduct constructed under Agrippa's guidance and the first in Rome constructed almost fifty percent above ground $[74,78]$. Agrippa built the Virgo primarily to provide water for a public bath, the first such facility in the city, as well as to provide water for related pleasure-sonrces, including gardens, a lake, and athletic facilities $[74,75,79,85]$. Such places became major sources of pleasure and water consumption in Roman culture.

Rome's water supply developed like those of earlier and contemporary cities, depending on wells, cisterns, springs and the Tiber River to provide water even after aqueducts came into $[78,87]$.
The second and related impetus for the boom in aqueduct construction during the early Principate was the development of concrete $[88,89]$.Van-Deman states that, although there were no new principles of construction involved in the building of Roman aqueducts, the change in material and methods enabled builders to construct impressive public works in a manner never before possible [79].

It was the Roman desire for more practical solutions to engineering problems which led them to experiment with construction technology, and which helped them to overcome the use of excessive amounts of materials to solve theoretical problems. The Roman solution was the creation of regular concrete and the perfection of hydraulic concrete. Concrete became adopted, in various forms, throughout the Mediterranean possibly from as early as the third century BC $[61,88,90]$ although the first use of concrete, opus caementicium, in a building of a certain date, comes from Rome's Temple of Concord 121 BC [79].

It was the use of the new construction material and technique, combined with age- old solutions to the problems of water supply that led to the erection of the now famous Roman aqueducts. Many Roman aqueducts seem to have been constructed originally to supply water for public baths. This appears to be true for many aqueducts and imperial thermae built during the Principate.

Just as the waterworks in the city of Rome continued to expand, so did the Roman sphere of influence. Soon, the impetus for providing water in both established and newly founded cities led to the appearance of Roman type systems throughout the Mediterranean region. Examples of the Roman water supply systems could be found inside Italy $[91,92]$ and as for away as Syria. In Antioch, Julius Caesar ordered an aqueduct built for the people on the upper mountain because they had never had the benefit of running water [93].

Roman military engineers probably constructed this aqueduct, which was built in part to serve the bath which Caesar erected there [93]. It did not take Roman leaders, however, to spread the idea of building Roman style aqueducts. Antiochus IV appears to have employed Cossutius, possibly a Roman architect, to build an aqueduct for Antioch in the mid second century BC [38]. Many Greek cities also began to replace their pipeline with channels built in the Roman fashion [42]. Certain basic characteristics can be found in aqueducts throughout the Roman world but, because they were practical builders, Romans and locals used indigenous materials when possible, such as kurkar at Caesarea and a calcareous stone and volcanic tufa at Pompeii. Later, poorer stones were used and encased [18-19]. At Pompeii, volcanic activity contaminated the ground water making it necessary to rely on cisterns for the provision of drinking water, rather than on wells or springs [1].

If a cistern was constructed relatively close to the courtyard surface, the water within assumed either the temperature of the ground or an intermediate temperature between ground temperature and air temperature, that is, a relatively warm temperature this means, for instance, that the water retrieved from 
one of the prominent above-ground cisterns at Pompeii would have been at least at air temperature, possibly warmer. For this reason, cisterns rarely supplied drinking water if a choice was available. If cisterns were to supplement drinking water, they were constructed more than six feet below the surface so that the water within remained at a cooler temperature [1]. The distance of the cistern from the courtyard surface, therefore, dictated whether the water within was meant primarily for sub-potable uses or as a supplementary supply of drinking water. That is not to say that well water was restricted solely to cooking and drinking needs [94]. That water could also be contaminated or stagnant. Because of the draw down principle, it is not advisable to have multiple wells operating within a small area [1]. Therefore, one is likely to find wells and cisterns in use in the same area.

Reservoirs and tanks were typically enlarged public cisterns. Construction of a large-scale system, which served several households, an entire neighbourhood, or a region of a city, was primarily the responsibility of the community through its leaders. These people often represented the government and could requisition, or have access to, the necessary manpower, funds and materials to carry out the more costly and time-consuming projects. The motivation for such involvement was not solely the desire to enhance the ordinary person's life, but also to be remembered as a patron and to show beneficence.

Dams linked to irrigation systems are a widespread phenomenon in arid areas, and come in many shapes and form In 1920s, the pioneering French archaeologist Poidebard photographed a particularly impressive example, the Harbaqa dam, which lies not far from Palmyra in Syria [95]. The Harbaqa dam at Qasr el-Heir el-Gharbi measures 345 metres in long, reaches a high of 30 metres, is 28 metres wide and is faced by large regular blocks of stone stepped upwards. At its base are three outlets from which a controlled measure of water could be released to a large reservoir downstream. From this reservoir, an intricate system of canals led to an irrigated valley system and a large artificial oasis garden. In essence, the system as a whole can be seen to be an ancient version of the modern reticulation system combining dams and canals, practised in many parts of the world today $[2,96]$. In between the reservoir and garden, a large mill complex was installed to make use of the power the flowing water could generate (Schlumberger $1939,1986)$. The whole complex has been dated to the first century AD.

An integral component of the system at Qasrel-Heir was the watermill, an ancient technology that has been identified at a number of locations in the arid lands of the Middle East. There are a number of variations in design, a reflection of several factors including the type of use the mill was put to, the position of the mill in relation to the rest of the water system in terms of available waterpower, and the state of technical knowledge at the time the mill was constructed. Some mills used water wheels in their operation, but others obtained more power by using primitive turbines: hence the development of the "Arubah penstock" or drop tower mill. In this system, the regular supply of water under high pressure needed to operate the machine was obtained by the use of an aqueduct or canal drain or millrace, cutting down the flow of water. The water quickly filled up the penstock and so maintained a constant high pressure as it gushed into the millrace. A small turbine was placed at the exit to the millrace, and the power generated by the rotation of the turbine was used to operate a set of grinding stones $([97,98]$. The date of origin of such drop tower mills, which have been found throughout the Middle East, has been much disputed in recent years $[99,100]$. Some examples in Jordan and Iran have been dated to the early Islamic period $[98,101]$ but cement in the drop tower mill at Wadi Faynan seems to contain material which would suggest an origin for these types of mills at least as early as the Roman period [102]. This conclusion has been supported by the discovery of a more technologically advanced turbine mill of the Roman period at Chemtou, Tunisia, which had three parallel turbines operating from a canal using an intricate sluice system [103,104].

Also, in Judea there are the numerous desert fortresses of the Hasmonean and Herodian monarchies at Alexandrion, Dok, Cypros, Hyrcania, Herodium, Masada and Machaerus, all of which required innovative engineering feats in order to ensure an adequate water supply. Depending on the hydrological and topographical situation of each fortress, the following procedures were used independently or in combination in order to collect and store water: 1) water catchment at springs, wadis or collecting channels; 2) conveyance of water by a channel to the foot of the hill or, when a bridge or pressure conduit was installed, to a point somewhere on its slope; 3) intermediate storage on the slope of the fortress hill to store a supply sufficient to allow for different availability over time; 4) transpiration by pack animals into cisterns in the fort for storage and consumption [61,105].

Herod the Great of Judea (40-4BC) is noted for his extensive building programmes, including waterworks such as aqueducts, reservoirs, fountains, baths and palatial gardens fitted with fountains and monumental swimming pools [106-111]. Roller attributes Herod's efforts in urban renewal in Judea and cities throughout the Near East to his visit to Rome in 40 BC [111]. Numerous extravagant monuments and public works were rebuilt, completed, started or conceived in the years immediately preceding Herod's initial visit to Rome, during a period of intensive urban development that marks Rome's transition into an imperial capital [111-113].

While Roman influence on Herodian architecture and engineering is undeniable, much of the hydraulic technology utilised to serve the needs of Herod's desert fortresses and the extravagant waterworks at his desert palaces at Jericho, Herodium, and Masada were already well developed locally. There is no better example of this than the hydraulic installations of the Nabataeans' who were accomplished in the technology of water management since the 4 th century BC $[114,115]$.

Aqueduct systems were widely developed and used new techniques that built on original Hellenistic, Roman and Byzantine concepts. This development went side by side with developments in other aspects of political, societal and economic life. 
Such techniques used in places were abundant with water resources of rainfall, springs and rivers, and were widely developed during the Roman era, which witnessed prosperity and advances in all areas of aqueduct systems channels, wells, reservoirs, dams and baths. Water-power was effectively exploited in empowering simple machines such as water mills, producing wheat grains after a process of milling wheat, a technique that was a breakthrough in the development of human civilisation [61] (Smith 1975: 205). In the Roman period, the Tripolitanian frontier zone was dotted with small outpost forts guarding wells, cisterns and oases on desert and pre-desert tracks, to regulate movement through the control of water sources [Mattingly 1995: 105].

Roman technology permeated the lands over which they held sway. For example, the use of concrete was not confined to Rome or Italy, but spread throughout the Roman world. Roman engineers also observed and followed nature's paths, including underlying geology, but did not necessarily let it dictate where or how they would build. Although the modern idea of control or domination of the environment was probably not conscious on the part of the Romans, it certainly was true when it came to how they handled many things, including water management. If the terrain did not suit their purpose, the Romans often altered it rather than change their plans. The cost of urban water systems continued to be a factor, but was not as restrictive a concern as before.

Advances in technology and the Pax Romana enabled the Romans to construct systems which were more open, that is., observable to the human eye, than had their predecessors. Long distance aqueducts were curious developments to the Greeks, who had reasons to be cautious of exposing such a lifeline or of seeking water which, might be technically with in, or close to, the limits of another polis territory. Greek and Hellenistic water lines also tended to have a relatively flat slope. If public aqueducts existed above ground, they were carried almost exclusively on groundhugging embankments and causeways, and if they needed to overcome a dramatic change in elevation, they utilised siphons. In such cases, Greek engineers, whose training came from the realm of architecture, pushed their technology to the limits [1].

A reservoir in Madaba at Jordan could hold about 42,750 cubic metres [La Bianca: 1992: 4]. Masada, west of the Dead Sea, was supplied with cisterns of up to 4,000cu.m, individually and together holding some 40,000 cu. m. [116]. The largest projects were meticulously planned systems of cisterns, channels and collecting surfaces. The only parallel to this seems to be the much larger socalled Majen cisterns recorded by the Libyan Valleys Survey in the Wadi Tininai lower Sofeggin basin, associated with Romano-Libyan, Islamic and coarse wares. The total capacity for all cisterns at the site is $300,000 \mathrm{~m}^{3}[117,118]$.

Ancient primitive civilisations developed in the oriental area on riverbanks where plenty of water sources are available. Therefore, the oldest canal systems are on the riverbanks of the Nile in Egypt and both the Tigris and the Euphrates in Mesopotamia [Smith 1975: 203; 2].
The urbanisation of ancient Jerusalem in the first millennium BC was enabled by a complex hydraulic system comprised of a natural spring (Gihon), tunnels, aqueducts, channels, pipes, catchment pools, reservoirs and cisterns. It is estimated that, by the Roman period (1st century AD), the city had enough water to sustain more that 75,000 inhabitants, including the demands of public works such as baths, pools and fountains [119]. Even the water of the famed Gihon Spring in Jerusalem was collected and controlled for later use because of its cyclical output (Shiloh 1984: 158). Human ingenuity was also needed when the distance between the location of the water source and the human community was too great or too dangerous to cross [120-130].

While Roman engineers, more skilled in civil engineering, continued to construct some long distance lines with minimum gradient, concrete enabled them to easily construct long sections of arcades, elevated, exposed and vulnerable, and to support these where needed [86]. Roman engineers did not consider siphons to be cost effective; instead they preferred to use bridges and arcades to solve the problem [1] (Aicher 1995: 17-18). The Romans did, however, use siphons to carry water above the first floor of private residences. As with so many other components in a water system, Roman engineers took existing technology, adapted it, even miniaturised it if necessary, and made it their own [1, 131-143].

Rome was not the originator of urban water systems, nor any of their components; it was, however, unquestionably a primary innovator. The Romans' practical approach to the problems of water supply enabled the grouping and utilisation of various wellknown water conveyance components to be handled in new ways. The ancient world's growing desire for luxury and pleasure spurred the demand for more water than was necessary simply to survive. Roman innovation in this area also led to changes in water provision to meet the demands for everything from baths and decorative fountains to creative sources of entertainment and the furnishing of private houses [144-152].

\section{Conclusion}

As can be seen from this brief overview of classical waterworks, there are noticeable differences between Greek, Hellenistic and Roman systems. Many are not striking distinctions but rather variations in problem-solving approach; others can be considered marked differences. Of course, exceptions can always be found to contradict the generalities presented here. Even so, by far the most obvious dissimilarity lies in the realm of technology or the application of existing technology. Greek and Hellenistic water management systems were regulated by the size of the city and the geology of the area in which it was located, not by available technology [1]. The Greeks applied only the necessary technology, partly defined by how much the community could afford to spend on the project [1,153-159].

The intention of this research is to trace various attempts to solve water supply problems, particularly in an urban setting where a large population occupies a relatively small physical 
area. There will be a brief discussion of general considerations of water provision for an eastern Mediterranean city, which became a Roman provincial capital. The research will deal primarily with classical Greek, Hellenistic, and Roman methods of water control management, even though many conditions and technological discoveries concerning water provision undoubtedly predate the fifth century BC. One of the points of the research is to note differences in water control, particularly between Hellenistic and Roman systems. In conclusion, the paper present a short discussion of how this information can be found at sites in Jordan.

Most cites utilised a supply system that included multiple components that supplemented each other and ensured adequate provision. Differences in components often depended on whether the supply was intended for public or private supply. Local distinctions in either particular components or an entire system were the result of various factors including security, wealth, geology, climate, desire, availability and preference. Distinctions between Greek, Hellenistic and Roman water supply should not necessarily be viewed as a sequential bettering of elements or construction. Such differentiation might pertain to when an element was first used but should not be seen as exclusive to a particular time or place. While each culture might focus more on certain elements than others, once initiated they then continued to be used through the ages. Builders used many of those components in the construction of ancient Jordan's water supply systems over time and often for the same reasons.

The parts of Jordan's water management system described in the future research reflect the era in which they were constructed, the desires of the population and the technological advances of the time. Excavators in Jordan are fortunate that most of the sites have not been covered with modern habitation, which restricts investigation. Nevertheless, with current building and population trends, this may not be true for much longer. It is these elements which make Jordan special in the quest to understand ancient urban water supply.

\section{Acknowledgment}

None.

\section{Conflict of Interest}

No conflict of interest.

\section{References}

1. Crouch D (1993) Water Management in Ancient Greek Cites. New York, USA.

2. Shqiara M (2005) The archaeology of water management in the Nabataean and Roman-Byzantine periods in Jordan: Overview and case studies from key sites. University of Bradford, UK.

3. Tolman F (1937) Groundwater. McGraw-Hill, New York, USA.

4. Smith N (1971) A History of Dams. Peter Davies, London, UK.

5. Steward H (1955) Irrigation Civilization: A Comparative Study. Pan American Union, Washington, USA.

6. Wittfogel A (1955) Oriental Despotism: A Comparative Study of Total Power. Yale University Press, New Haven CT, USA.
7. Spooner B (1974) City and river in Iran: urbanization and irrigation of the Iranian Plateau, Iranian Studies, Iran 7: 681-713.

8. Adams R (1981) Heartland of Cities: Surveys of Ancient Settlement and Land Use on the Central Floodplain of the Euphrates. University of Chicago Press, Chicago, USA.

9. Lang M (1968) Waterworks in the Athenian Agora (Excavations of the Athenian Agora, Picture Book 11). Princeton University Press, New Jersey, USA.

10. Thucydides (1962) History of the Peloponnesian War. Translated by Charles Forster. Loeb Classical Library. Harvard University Press, Cambridge, USA.

11. Toynbee A (1971) An Ekistical Study of the Hellenic City-State 1, Ancient Greek Cities. Athens Technical Organization/Athens Centre of Ekistics, Athens, Greece.

12. Blackman R (1978) The volume of water delivered by the four great aqueducts of Rome. Papers of the British School at Rome, USA, 46: 52-72.

13. Travlos J (1980) Pictorial Dictionary of Ancient Athens. Hacker Art Books. New York, USA.

14. Camp J McK II (1986) In: Thames, Hudson (Ed.), Excavations in the Heart of Classical Athens, The Athenian Agora, New York, USA.

15. Camp J McK II (1991) Water supply and its historical context. In: A Trevor Hodge (Ed.), Future Currents in Aqueducts Studies, Francis Cairns, Leeds, England, pp. 105-111.

16. Travlos J (1980) Pictorial Dictionary of Ancient Athens. Hacker Art Books. New York, USA.

17. Aristotle (1932) Politics. In: H Rackham (Ed.), Heinemann, London, UK.

18. Hodge T (1992) Roman Aqueducts and Water Supply. Duckworth, London, UK.

19. Herodotus (1946-1957) Translated by AD Godley. Loeb Classical Library. Harvard University Press, Cambridge, USA.

20. Diodorus Siculus (1960) Bibliotheca historica. Loab Classical Library. In: CH Old father (Ed.), Harvard University Press, Cambridge MA, USA.

21. Burns A (1974) Ancient Greek water supply and city planning: a study of Syracuse and Acrages, Technology and Culture 15: 389-412.

22. Dinsmoor B (1950) The Architecture of Ancient Greece: An Account of its Historical Development. ( $3^{\text {rd }}$ edn). Batsford, London, UK.

23. Thompson A (1966) Activity in the Athenian Agora 1960-1965. Hesperia, USA, 35: pp. 37-54.

24. Wycherley E(1978) The Stones of Athens. Princeton University Press, New Jersey, USA.

25. Owens J (1991) The Kremna Aqueduct and water supply in Roman Cities, Greece and Rome 38: 41-58.

26. Fahlbusch H (1987) Municipal water supply in Antiquity. In: O Walter, J Egbert Prins (Eds.), Water for the Future: Water Resources Developments in Perspective, pp. 113-123.

27. Chang Ho H (1998) Archaeological survey and settlement patterns in the region of 'Iraq Al-Amir 1996 a Preliminary Report, Annual of the Department of Antiquities of Jordan 42: 587-608.

28. Phillips W (1955) Qataban, Sheba: Harcourt Brace, New York, USA.

29. Hoyland G (2001) Arabia and the Arabs: from the Bronze Age to the coming of Islam. Routledge, London, UK.

30. Owens J (1992) The City in the Greek and Roman world. Routledge. London, UK.

31. Jacobsen T, S Lloyd (1935) Sennacherib's Aqueduct. The University of Chicago Press, USA.

32. Halpern-Zylberstein and M.Christine (1989) The Archaeology of Hellenistic Palestine. In: W Davies, L Finkelstein (Eds.) The Cambridge History of Judasim. The Hellenistic Age, Cambridge: Cambridge University Press. USA, 2: pp.1-34. 
33. Thompson A (1948) The excavations of the Athenian Agora $12^{\text {th }}$ season: 1947, Hesperia, USA, 17: 149-196.

34. Thompson DB (1954) Three centuries of Hellenistic Terracottas, Hesperia 23: 72-107.

35. Halpern Zylberstein, M Christine (1989) The Archaeology of Hellenistic Palestine. In: W Davies, L Finkelstein (Eds.) The Cambridge History of Judasim. The Hellenistic Age. Cambridge: Cambridge University Press, USA, $2: 1-34$.

36. Jansen M (1991) Water Systems and Sanitation in the House of Herculaneum. Mededelingen van het Nederlands Institut to Rome (Papers of the Netherlands Institute in Rome: Antiquity) 50: 145-166.

37. Tomlinson R (1992) From Mycenae to Constantinople: The Evolution of the Ancient City. Routledge. London, UK.

38. Downey G (1951) The water supply of antioch on the orontes in antiquity, Les annales Archeologiques de Syrie 1: 171-187.

39. Wilber N (1938) The Plateau of Daphne: the spring and the water system leading to Antioch. In R. Stillwell (ed.) Antioch on the Orontes II: The Excavations 1933-1936: Princeton: Princeton University Press, New Jersy, USA Pp49-56.

40. Frankel R (1985) The Hellenistic aqueduct of Acre-Ptolemais, Atiqot (English series) 17: 134-138.

41. Alcock E (1993) Graecia Capta: the landscapes of Roman Greece. Cambridge University Press, Cambridge, UK.

42. Coulton J (1987) Roman Aqueducts in Asia Minor. In: S Macready, F Thompson (Eds.) Roman Archaeology in the Greek World: Society of Antiquaries of London Occasional Papers. Burlington House, New Series X. London, UK, pp. 72-84.

43. Tsuk T (1997) Hydraulics. In EM Myers (eds.), The Oxford Encyclopaedia of Archaeology in the Near East 3: 130-132. Oxford University Press, New York, USA.

44. Zayadine F (1977) Excavations on the upper citadel of Amman, Area A (1975 and 1977), Annual of the Department of Antiquities of Jordan 22: 20-45.

45. Browning I (1981) Jerash and the Decapolis. Butler and Tanner, London, UK.

46. Shqiarat, M (1999) Water systems in the site of Al-Yasileh during the Roman and Byzantine Ages. Unpublished MA thesis, Department of Archaeology, Yarmouk University, Irbid, Jordan.

47. Yassin K (1991) Southern Sham Land history and archaeology in Bronze Period. [in Arabic]. Amman: University of Jordan Press, Jordan.

48. Meyers M (1997) The Oxford Encyclopaedia of Archaeology in the Near East. Oxford University Press, New York, USA.

49. Piccirillo M (1985) Rural settlement in Byzantine Jordan. Studies in the History and Archaeology of Jordan 2: 257- 261.

50. Schick R (1995) The Christian Communities of Palestine from Byzantine to Islamic rule: A Historical and Archaeological Study. Princeton : Darwin Press, USA.

51. Kaegi W (1966) The Fifth-Century Twilight of Byzantine Paganism, in Classica et Mediaevalia 27: 243-75.

52. Hohlfelder R (19820) Twilight of Paganism in the Holy Land: Numismatic evidence from the excavations at Tell er Ras, in City, town and countryside in the early Byzantine era.

53. Mac Mullen R (1984a) Christianising the Roman Empire AD100-400. New Haven CT: Yale University Press, New Haven.

54. Mac Mullen R (1984b) The legion as a society, Historia 33: 440-456.

55. Zeyadeh A (1988) An Archaeological Assessment of Six Cities in al-Urdun from the Fourth Century to the Mid-Eighth century AD. [in Arabic]. (Unpublished MA thesis). Institute of Archaeology and Anthropology, Yarmouk University, Jordan.

56. Al-Shqiarat M (2018) Water Management in Jordan Past. Present and Future Lambert Academic Publishing.
57. Shqiarat M (2008) The Archaeology of Water Control in the Nabataean and Roman-Byzantine Periods in Jordan: Overview and Case Studies from Key Sites, Cura Aquarum in Jordanien 21: 45.

58. Shqiarat M, Al Salameen Z, Faulkner N, Saunders N (2011) Fire and water: tradition and modernity in the archaeology of steam locomotion in a desert war. Levant issue 4(31) 98-133.

59. Avi Yonah M (1958) The economics of Byzantine Palestine. Israel Exploration Journal 8(1): 39-51.

60. Tsafrir Y (1996) Some notes on the settlement and demography of Palestine in the Byzantine Period: the archaeological evidence, in retrieving the past: essays on archaeological research and methodology. In G VanBeek, J Seger (eds). Published by Eisenbrauns for the Cobb Institute of Archaeology 269-283.

61. Shqiarat M (2018) Abandoning Shammakh: Historical Archaeology among the Villages of Southern Jordan and its Ethno-Archaeological and Modern Economic Potential. Journal of Anthropology and Archaeology 6(1): 1-14.

62. Shqairat, M Abudanh, F Twaissi, (2010) Water Management and RockCut Cisterns with Special Reference to the Region of Udhruh in Southern Jordan. Journal of History and Archaeology of Jordan 4(2): 205-227.

63. Hopkins K (1980) Taxes and trade in the Roman Empire, Journal of Roman Studies 70: 132-121.

64. Levy J (1967) The Economic Life of the Ancient World. Chicago: University of Chicago Press, USA.

65. Reece R (1981) Roman monetary impact on the Celtic world - thoughts and problems. In: B Cunliffe (Ed.), Coinage and society in Britain and Gaul: some current problems (CBA Research Report 38): 24-28.

66. Meyers M (1982) Byzantine Towns of the Galilee, In L Hohlfelder (ed). And Countryside in the Early Byzantine era, Robert. Eastern European Monographs, No. CXX. Byzantine Series, No.1. Columbia University Press, New York, USA.

67. Issac B (1998) The Decapolis in Syria: A Neglected Inscription, in The Near East Under Roman Rule, Selected Papers. Brill, Leiden.

68. Kennedy D (1998) The identity of Roman Gerasa: an archaeological approach, Mediterranean Archaeology 11: 39-69.

69. Seigne J (1997) Les Limites orientale et méridionale du territoire de Gerasa, Syria, Middle East, Pp74 : 121-38.

70. Mundy M (1996) “Qada” 'Ajlun in the late nineteenth century: interpreting a region from the Ottoman land registers, Levant, Asia 28: 77-95.

71. Whitby M (1995) Recruitment in Roman Armies from Justinian to Heraclius (ca.565-615). In A Cameron (ed.). The Byzantine and Early Islamic Near East 3: States, Resources and Armies. (Studies in Late Antiquity and early Islam 1/Papers of the Third Workshop on Late Antiquity and Early Islam): 61-124.

72. MacAdam H (1994) Settlements and Settlement Patterns in Northern and Central Transjordania. In G. King and A. Camerond(ed) The Byzantine and Early Islamic Near East: 53-68.

73. Clark G (1944) Water in Antiquity, Antiquity 18: 1-15.

74. Frontinus, Sextus Julius (1969) De Aquis Urbis Romae. In: Charles E Bennett. Loeb Classical Series. Harvard University Press, Cambridge, USA.

75. Pliny the Elder (1962) Natural History. In: H Rackham (ed.). Loeb Classical Library. Cambridge: Harvard University Press.

76. Landels G (1978) Engineering in the Ancient World. Berkeley: University of California Press, USA.

77. Oleson J (1991) Aqueducts, cisterns and the strategy of water supply at Nabataean and Roman Aura Jordan. In: A Hodger (Ed.), Future Currents in Aqueducts Studies. Leeds: Francis Cairns, UK.

78. Louis P (1965) Ancient Rome at Work: An Economic History of Rome from the Origins to the Empire. Barnes and Noble, New York, USA.

79. Van Deman E, B Esther (1973) The Building of the Roman Aqueducts. Washington: Carnegie Institution of Washington, 1934; reprint, Washington: Mc Grath, USA. 
80. Butler H (1901) The Roman Aqueducts as Monuments of Architecture, American Journal of Archaeology 5: 175-199.

81. Vitruvius (1962) De Architectura. Translated by Frank Granger. Loeb Classical Library. Harvard University Press, Cambridge, USA.

82. Dunbabin D (1989) 'Baiarum grata voluptas': pleasures and dangers of the baths. Papers of the British School at Rome 57: 7-46.

83. Mac Donald B (1987) Southern Ghors and Northeast Arabah Archaeological Survey, Jordan 1986: a preliminary report. Annual of the Department of Antiquities of Jordan 31: 391-413.

84. Rook T (1992) Roman Baths in Britain. Princes Risborough: Shire Archaeology, Europe.

85. Zanker P (1988) The Power of Images in the Age of Augustus (Translated by Alan Shapiro). Ann Arbor: University of Michigan Press, Ann Arbor.

86. Prager D (1978) Vitruvius and the Elevated Aqueducts. History and Technology 3: 105-121.

87. Bruun C (1991) The Water Supply of Ancient Rome: a study of Roman Imperial Administration. (Society Scientiarum Fennica. Commendations Human arum Litter arum 93). Finnish Society of Sciences and Letters, Helsinki, Finland.

88. Davey N (1965) A History of Building Materials. (2 $2^{\text {nd }}$ edn) Phoenix House, London, UK.

89. Blake M (1947) Ancient Roman Construction in Italy from the Prehistoric period to Augustus. Carnegie Institute, Washington, USA.

90. Van Deman E (1912) Methods of determining the date of Roman concrete monuments (Second Paper), American Journal of Archaeology 16: 387-464.

91. Mc Cann A (1985) The Roman port and fishery of Cosa: a centre of trade in the late Roman Republic. In A. Raban (ed.s) Harbour Archaeology. (Proceeding of the first International Workshop on Ancient Mediterranean Harbours, Caesarea Maritima 24-28 th June 1983. Centre for Maritime Studies, Haifa University and CAHEP Publications 1): 115156. Oxford: BAR International Series 257

92. Brown E (1980) Cosa: The Making of a Roman Town. $13^{\text {th }}$ Series. University of Michigan Press, Ann Arbor, USA.

93. Downey G (1961) A History of Antioch in Syria from Seleucus to the Arab Conquest. Princeton: Princeton University Press, USA.

94. Young R (1951) An industrial district of ancient Athens, Hesperia 20: 135-288.

95. Poidebard A (1934) Le Trace de Rome dans le Desert de Syrie: Le Limes de Trajan a la Conquete Arabe, Recherches Aeriennes. Paul Geuthner, Paris, France, Europe.

96. Heathcote L (1983) The Arid Lands: their use and abuse. Longman, London, UK.

97. Avitsur S (1960) On the history of the exploitation of water power in Ersetz-Israel. Israel Exploration Journal 10: 37-45.

98. Neely A (1974) Sassanian and early Islamic water control and irrigation systems on the Deh Luran plain, Iran. In: T Downing, M Gibson (Edts.), Irrigation's Impact on Society, University of Arizona Press, USA,Pp 2144.

99. Mc Quitty A (1995) Water-mills in Jordan: technology, typology, dating and development: art and technology throughout the Ages, Studies in the History and Archaeology of Jordan 5: 745-51.

100. Wilson A (1995) Water-mills in North Africa and the development of the horizontal water-wheel, Journal of Roman Archaeology 8: 499-510.

101. Gardiner M, A Mc Quitty (1987) A water mill in the Wadi el-Arab, North Jordan and water mill development, Palestine Exploration Quarterly 119(1): 24-32.

102. Barker GW, R Adams, OH Creighton, Crook, DD Gilbertson, et al. (1997) Environment and land use in the Wadi Faynan, Southern Jordan: the second season of geoarchaeology and landscape archaeology. Levant 30: 25-27.
103. Wilson A (1996) Recent studies on aqueducts and water supply, Journal of Roman Archaeology 9: 25-29.

104. Wilson A (2003) Late antique water-mills on the Palatine, Papers of the British School at Rome 71: 85-109.

105. Garbrecht G, Y Peleg (1994) The water supply of the desert fortresses in the Jordan Valley, Biblical Archaeologist 57: 161-170.

106. Netzer E (1975) The Hasmonean and Herodian Winter Palaces at Jericho, Israel Explorations Journal 25: 89-100.

107. Netzer E (1977) The winter palaces of the Judean kings at Jericho at the end of the second temple period, Bulletin of the American Schools of Oriental Research 228:1-13.

108. Netzer E (1981) Greater Herodium: Israel Exploration Society, Jerusalem.

109. Netzer E (1985) The Swimming Pools of the Hasmonean Period at Jericho In: Hebrew, Eretz (eds.), Israel, 18: 344-352.

110. Gleason L, B Burrell, E Netzer, L Taylor, J Williams (1998) The promontory palace at Caesarea Mariyima: preliminary evidence for Herod's Praetorium, Journal of Roman Archaeology 2: 23-52.

111. Roller W (1998) The Building Program of Herod the Great. Berkeley: University of California Press, USA.

112. Roller W (1983) The Ain Laban Oasis: A Nabataean population centre, American Journal of Archaeology 87(2): 173-182.

113. Favro D (1996) The Urban Image of Augustan Rome. Cambridge: Cambridge University Press, Cambridge, USA.

114. Hammond P (1973) The Nabataeans: Their History, Culture and Archaeology. Gotheburg, Sweden: Paul Astroms.

115. Ball W (2000) Rome in the East: Transformation of an Empire. Routledge, London, UK.

116. Yadin Y (1966) Masada: Herod's Fortress and the Zealots' Last Stand. London: Sphere, UK.

117. Mattingly DJ (1999a) The Bronze Age Landscape in WF.13 (site WF 100). 269-271.

118. Mattingly DJ (1996b) Explanation: People as agency. In G.Barker (eds.). Farming the desert: (The UNESCO Libyan Valleys Archaeological Survey 1- Synthesis:319-42.

119. Wilkinson C (1974) Ancient Jerusalem: its water supply and population, Palestine Exploration Quarterly 106: 33-51.

120. Adams R (1974b) Historic Patterssns of Mesopotamian Irrigation Agriculture. In T Downing, M Gibson (Eds.), Irrigation's Impact on Society, University of Arizona Press, Tucson, USA, pp. 1-5.

121. Adams R (1955) Developmental Stages in Mesopotamia. In: J Steward (Ed.), Irrigation Civilisations: A Comparative Study. Washington Carnegie Institute, USA

122. Adams R (1974a) Anthropological perspectives on ancient trade. Current Anthropology 15: 3-16.

123. Blake M (1973) Roman Construction in Italy from Nerva through the Antonines. In: Doris Taylor Bishop, Foreword, J David Bishop (Eds.), American Philosophical Society, Philadelphia, USA.

124. Browning I (1973) Petra. In: Chatto, Windus (Eds.), London, UK.

125. Browning I (1989) Petra ( $3^{\text {rd }}$ edn). In: Chatto, Windus (Eds.), London, UK.

126. Camp J McK II (1986) In: Thames, Hudson (Eds.) The Athenian Agora: Excavations in the Heart of Classical Athens. New York.

127. Clark G (1960) Archaeology and Society. Methuen, London, UK.

128. Crouch D (1984) The Hellenistic water system of Morgantina, Sicily: contributions to the history of urbanisation, American Journal of Archaeology 88: 353-365.

129. Crouch D (1987) Water System Evidence of Greek Civilisation. In: Walter 0 Wunderlich, J Egbert Prins (Eds.) Water for the Future 
Water Resources Developments in Perspective. (Proceedings of the International Symposium on water for the Future, Rome 6-11 April 1987). Rotterdam, Netherlands, pp. 125-138.

130. Crouch D, K Rinne (1996) Aquae Urbis Romae: an historical overview of water in the public life of Rome. In $\mathrm{N}$ de Haan, Babessch, $\mathrm{G}$ Jansen (Eds.) Cura Aquarum in Campania (Proceedings of the Ninth International Congress on the History of Water Management and Hydraulic Engineering in the Mediterrannean Region. Pompeii, 1-8 October 1994). 145-151.

131. Fan Zeal A (1990) Al-Amoebaeans. [In Arabic, translated from English by K Yassine] Amman: University of Jordan Press, Jordan.

132. Hodge T (1991) (editor) Future Currents in Aqueduct Studies. Leeds:

133. Hodge T (1996) 'In Vitruvium Pompeianum': urban water distribution reappraised, American Journal of Archaeology 100: 261-276.

134. Boulder: East European Monographs no. CXX Byzantine Series no. 1: 75-110.

135. Isaac B (1980) Trade-routes to Arabia and the Roman army. In W Hanson, L Keppie (eds.) Roman Frontier Studies 1979 (Oxford: BAR International Series 71(iii)): 889-901.

136. Issar A, D Yakir (1997) Isotopes from wood Buried in the Roman Siege Ramp of Masada: The Roman Period Colder Climate, Biblical Archaeologists 60(2): 101-106.

137. Mac Donald L, J Pinto (1995) Hadrian's Villa and its Legacy. Yale University Press, New Haven.

138. Mango C (1980) Byzantium the Empire of New Rome. Scribner, New York, USA.

139. Mc Quitty A (2001) The Ottoman Period. In B Mac Donald, R Adams, P Bienkowski (eds.). The Archaeology of Jordan: Academic Press, Sheffield, England. 515-560.

140. Plutarch (1967) Life of Grassus. In: Plutarch, Parallel Lives(eds.), (10 Volumes) Translated by Bernadotte Perin. Loeb Classical Library. Cambridge, MA: Harvard University Press, USA.

141. Rook T (1992) Roman Baths in Britain. Princes Risborough: Shire Archaeology.

142. Schlumberger D (1939) Les Fouilles de Qasr el-Heir el-Gharbi. Rapport préliminaire $20: 195-238$, Syria.

143. Schlumberger D (1986) Qasr el-Heir el-Gharbi (Bibliothèque archéologique et historique 120 : Paul Geuthner, Paris, France, Europe.

144. Shiloh Y (1984) Excavations on the City of David I (1978-1982), Qedem 19, Monographs of the Institute of archaeology, The Hebrew Unversity of Jerusalem. Institute of Archaeology, Hebrew University, Israel.
145. Thompson A (1956) Activities in the Athenian Agora: 1955, Hesperia 25: 46-68.

146. Thompson DB (1954) Three centuries of Hellenistic Terracottas, Hesperia 23: 72-107.

147. Travlos J (1980) Pictorial Dictionary of Ancient Athens. Hacker Art Books, New York, USA.

148. Tsafrir Y (1976) Symmetry at Herodian, megalomania in Herodian architecture, and the Place of Roman technology, The Jerusalem Cathedra, Israel,Pp 1: 68-72.

149. Van Deman E (1912) Methods of determining the date of Roman concrete monuments (Second Paper), American Journal of Archaeology 16: 387-464.

150. White K (1984) Greek and Roman Technology. Ithaca: Cornell University Press, New York, USA.

151. Wilkinson A (1998) The Garden in Ancient Egypt. London: Rubicon Press, UK.

152. Wilkinson A (1998) The Garden in Ancient Egypt. Rubicon Press, London, UK.

153. Wilkinson C (1977) Water and Tribal Settlement in South-East Arabia: a study of the Aflaj of Oman. Oxford: Clarendon Press, Middle East.

154. Wilson A (2001) Urban water storage, distribution and usage in Roman North Africa. In A Koloski Ostrow (ed.), Water use and hydraulics in the Roman city (Archaeological Institute of America Colloquia and Conference Papers, New series, 3): 83-96.

155. Wilson A (2004) Classical water technology in the early Islamic world. In C. Bruun, A Saastamoinen (eds.), Technology, ideology, water: from Frontinus to the Renaissance and beyond (Acta Instituti Romani Finlandiae 31): 115-41.

156. Withe G (1999) Committee on Sustainable Water Supplies, Water for the Future: The West Bank and Gaza Strip, Israel and Jordan. Washington, USA.

157. Yadin Y (1963) The Finds from the Bar Kokhba Period in the Cave of the Letters. Jerusalem: Israel Exploration Society/Hebrew University, Israel.

158. Yassin K (1979) Archaeology of Jordan.: University of Jordan Press, Amman.

159. GW Barker, R Adams, OH Creighton, D Crook D, D gibertson, et al. (1998) sEnvironment and Land Use in the Wadi Faynan, Southern Jordan: the Third Season of Geoarchaeology and Landscape Archaeology Levant 31: 255-292. 